FUJI ASTUTI DAN YANI KUSMARNI

REKAM JEJAK PERJUANGAN PASUNDAN ISTRI (PASI) DI BANDUNG 193O-197O

\title{
REKAM JEJAK PERJUANGAN PASUNDAN ISTRI (PASI) DI BANDUNG 1930-1970
}

\author{
Oleh: \\ Fuji Astuti dan Yani Kusmarni ${ }^{1}$
}

\begin{abstract}
This article titled as "Kiprah Pasundan Istri (PASI) di Bandung on 1930-1970". The main purpose in this research is to describe history Pasundan Istri organization background in 1930, to describe of development Pasundan Istri organization between 1930-1970 and to analyze the struggle effect of Pasundan Istri organization toward Women education between 1930-1970. To achieve research goals, the Historic Method used in this research consisting of heuristic, critical resources, interpretation and historiography, which of the sources obtained through study literature. In this regard, the study intended that the ideals and efforts of Pasundan Istri can be continued by Sundanese women in particular and Indonesian women in general. From the results, the researcher obtained data about the role of PASI which was established on April 30, 1930. This organization formed under the management of the Pasundan Association and founded by Mrs Emma Poeradiredja with 8 other women activists. Even though it is under the auspices of the Paguyuban Pasundan organization, PASI basically has a reglament and its own central committee named Centra Bestuur or Rengrengan Sesepoeh Pasoendan Isteri. At the beginning of its formation this organization was named Pasoendan Bagian Isteri (PBI), but in 1931 RSPI decided to change its name to Pasundan Istri (PASI) and selected Emma Poeradiredja as general chairman of PASI. $P A S I$ began the struggle initial steps by educating women and society in general by contributing to women's empowerment in the form of a broad education. High sense of empathy and an effort to preserve regional cultural arts. This research is expected to be useful in learning history in schools, especially at the high school level and be a recommendation for other research on local history.
\end{abstract}

Keywords: Emma Poeradiredja, Education, Organization, Pasundan Istri

\section{PENDAHULUAN}

Pergerakan yang dilakukan oleh kaum perempuan muncul pada masa penjajahan Hindia Belanda memang memiliki peranan tersendiri dalam sejarah panjang perjalanan bangsa Indonesia. Kontribusinya dalammengisikemerdekaan tidak dapat dipandang sebelah mata. Hal ini dikarenakan perempuan mempunyai peranan yang sangat besar dalam keluarga sebagai seorang istri dan ibu serta sebagai bagian dari bangsa Indonesia. Akan tetapi pada kenyataannya penulisan mengeni sejarah perempuan masih minim dibandingkan dengan penulisan yang menceritakan sejarah kaum pria baik secara kuantitas maupun kualitas. Di Indonesia masih jarang ditemui tulisan-

${ }^{1}$ Fuji Astuti adalah mahasiswa pada Departemen Pendidikan Sejarah FPIPS UPI, Yani Kusmarni adalah dosen pembimbing I. Penulis dapat dihubungi di alamat email: fujiaaastuti@yahoo.com 
tulisan yang membahas mengenai peranan wanita serta pergerakan organisasi wanita di daerah, padahal kontribusi perempuan tersebut sama berpengaruhnya dengan kaum pria. Menurut Fatimah (2008, hlm. 389) terdapat beberapa alasan mengapa penulisan sejarah perempuan di Indonesia tergolong lambat yang dapat dipahami melihat kenyataannya yang ada. Pertama, paradigma yang keliru tentang sejarah perempuan. Kedua dari segi metodologi yaitu adanya perspektif yang keliru tentang dunia perempuan berpengaruh kepada faktor lainnya yakni persoalan sumber.

Selain itu permasalahan mengenai kaum perempuan yang masih jarang ditulis sejalan dengan pendapat Indraswari (2018, hlm. 69) yakni diharapkan dengan adanya penelitian ini wacana mengenai perempuan akan kaya. Selain itu pula karya ilmiah ini berguna untuk melengkapi penulisan-penulisan mengenai perempuan berdasarkan perspektif perempuan itu sendiri. Masih banyak pendapat yang menganggap masalah perempuan merupakan ranah domestik (privat). Sementara urusan keilmuan merupakan ranah publik, bukan hanya identik dengan dunia pria saja. Tetapi pada realisasinya urusan perempuan selalu dianggap privat dan sebagaian besar dokumen berurusan dengan ranah publik. Oleh karena itu tidak menutup kemungkinan, perempuan menjadi terlupakan dan terabaikan dari catatan sejarah.

Hal tersebut relevan dengan organisasi Pasundan Istri sebagai salah satu organisasi pemberdayaan perempuan yang cukup berpengaruh serta sebagai organisasi kaum perempuan yang memiliki kepedulian terhadap adat dan budaya Sunda dan berkeinginan besar untuk terus melestarikan dan menjunjung kebudayaan tersebut. Selain itu PASI terbentuk oleh situasi kaum perempuan pada periode tersebut yang dipenuhi dengan penyelewengan hak-hak perempuan di Indonesia khususnya kaum perempuan di tatar Sunda. Kedudukan perempuan yang pada saat itu dapat dikatakan sangat memprihatinkan, salah satu diantaranya disebabkan karena tidak ada kebijakan dari pemerintah Hindia Belanda mengenai pendidikan yang layak bagi kaum perempuan terkecuali kaum perempuan yang berasal dari golongan bangsawan dan priyayi. Kondisi tersebut semakin diperparah oleh keadaan masyarakat Indonesia yang masih beranggapan stereotype mengenai kaum perempuan yang mendapatkan pendidikan dianggap sebagai upaya penentangan terhadap nilainilai leluhur dan budaya.

Meskipun demikian hal tersebut tidak menjadikan semangat dari anggota PASI luntur untuk terus memajukan harkat dan martabat perempuan. Organisasi ini berusaha bergerak berjuang meningkatkan harkat dan martabat kaum perempuan serta berusaha menumbuhkan kepeduliannya terhadap pendidikan kaum perempuan di tatar sunda. Melalui pergerakan bersama aktivis perempuan lain semakin gencar melakukan kegiatankegiatan sosialnya serta berjuang untuk memperbaiki kedudukan sosial termasuk kemajuan dalam hal pendidikan bagi kaum perempuan di tatar Sunda. Usaha yang dilakukan oleh PASI dalam melepaskan belenggu ketidakadilan atas hak-hak perempuan dibuktikan melalui kegiatan-kegiatan sosial, seperti perbaikan pendidikan kaum perempuan dalam hal membaca, menulis, serta keterampilanketerampilan seperti memasak, menjahit, dan belajar mengenai perkoperasian. 
selain usaha pemberdayaan dalam lingkup regional, PASI juga turut berpartisipasi secara nasional bersama organisasi wanita lain dengan berperan aktif dalam setiap Kongres Perempuan Indonesia.

Pemberdayaan perempuan di Jawa Barat yang dilakukan oleh organisasi Pasundan Istri (PASI) hingga saat ini masih terasa keberadaannya. Akan tetapi pada realitanya urusan dan peranan organisasi Pasundan Istri tidak terlalu disoroti dan sumber-sumber sejarah tidak terlalu diperhatikan padahal sumber tersebut dapat menunjang dalam kemajuan bangsa khususnya kemajuan kaum perempuan. Hal ini kemudian penulis tunjukan dengan karya ilmiah ini. PASI ialah suatu organisasi yang cukup berperan di Indonesia khususnya di Jawa Barat. Pencapaian-pencapaian yang telah diraih oleh organisasi PASI sebagai salah satu organisasi pergerakan kaum perempuan yang cukup diperhitungkan dari organisasi tingkat lokal hingga tingkat provinsi, nasional bahkan internasional. Hal ini pula yang dapat menginspirasi pergerakan-pergerakan perempuan lain di daerah-daerah.

Dalam penyusunan karya ilmiah, penulis menggunakan beberapa sumber berupa buku, surat kabar serta sumber lainnya sebagai kajian pustaka. Hal ini dilakukan agar penulis dapat mengembangkan landasan berpikir dalam mengkaji dan menganalisis permasalahan mengenai sejarah perkembangan organisasi Pasundan Istri di Bandung pada tahun 1930-1970. Adapun tujuan yang ingin dicapai dalam penelitian ini adalah:

1. Memperoleh gambaran perkembangan pergerakan kaum perempuan di Indonesia sebelum berdirinya organisasi Pasundan Istri.
2. Mendeskripsikan perkembangan organisasi Pasundan Istri di Bandung pada tahun 1930-1970.

3. Mengetahui dan mendeskripsikan dampak dari perjuangan organisasi Pasundan Istri (PASI) terhadap pendidikan kaum perempuan di Jawa Barat pada tahun 1930-1970.

Penelitian ini juga memiliki beberapa manfaat yang diantaranya adalah:

1. Secara teoritis, karya ilmiah ini diharapkan akan memiliki fungsi edukatif yakni memberikan pembelajaran dari peristiwa masa lalu kaitannya dengan penelitian ini adalah menambah pengetahuan bagi penulis pada khususnya dan bagi pembaca pada umumnya mengenai kiprah organisasi perempuan dan kelaskaran di Bandung sehingga memunculkan rasa cinta pada sejarah lokal.

2. Kegunaan praktis ialah karya ilmiah ini akan memberikan kontribusi sebagai pelengkap tulisan sejarah perempuan dan menambah referensi mengenai sikap dan pandangan kaum pemuda putri terhadap kondisi pemerintahan di Indonesia khususnya di Bandung pada saat masa pergerakan nasional dan dapat berguna bagi penelitian yang lebih luas dan lebih mendalam dalam rangka menambah dan memperdalam khasanah penulisan sejarah.

\section{METODE PENELITIAN}

Penulisan artikel ini menggunakan metode historis. Metode historis adalah proses penyajian dan analisis secara kritis terhadap rekaman serta peninggalan masa lampau dan menuliskan hasilnya berdasarkan fakta yang telah diperoleh yang terdapat dalam historiografi 
(Gottschalk, 2008, hlm. 32). Ismaun (2005, hlm. 34) menjelaskan mengenai metode sejarah ialah rekonstruksi imajinatif tentang gambaran masa lampau peristiwa-peristiwa sejarah secara kritis dan analitis berdasarkan bukti-bukti dan data peninggalan masa lampau yang disebut sumber sejarah. Pendapat lainnya ialah menurut Edson (dalam Supardan, 2007, hlm. 306) dimana metode historis merupakan langkah-langkah, "define the problems or questions to be investigated; search for sources of historical facts; summarize and evaluated the historical sources; and present the pertinent facts within an interpretative framework".

Metode historis merupakan cara untuk mengkaji suatu peristiwa, tokoh, atau permasalahan yang dianggap layak dan penting yang terjadi pada masa lampau secara deskriptif, kritis dan analitis. Penelitian sejarah tidak hanya mengungkapkan suatu peristiwa secara kronologis, lebih dari itu perlu adanya kajian dan analisis tajam yang didukung dengan teori yang relevan. peneliti sejarah harus memiliki kemampuan untuk melaksanakan proses penelitian yang dapat dipertanggung jawabkan. Adapun penulis menggunakan metode penelitian yang dijelaskan oleh Sjamsuddin dalam bukunya Metodologi Sejarah.

Langkah-langkah yang dilakukan dalam penelitian sejarah menurut Sjamsuddin (2012, hlm. 89), antara lain: memilih topik penelitian; mengusut semua evidensi yang relevan dengan topik; dalam tahap ini peneliti mencari sumbersumber yang mendukung terhadap kajian penelitian. Dalam hal ini penulis menggunakan buku dan surat kabar serta artikel dan data-data lain baik dari internet, perpustakaan maupun lembaga terkait. Membuat catatan-catatan penting yang dianggap relevan dengan topik; mengevaluasi secara kritis semua evidensi yang telah dikumpulkan, terutama melakukan kritik eksternal terhadap narasumber yang akan diwawancarai. Mereka harus memiliki keterhubungan dengan topik penelitian yang dikaji; disini peneliti juga menggunakan kritik internal terhadap setiap pernyataan yang diungkapkan oleh narasumber guna menghindari unsur subjektifitas.

Dengan demikian, akan dapat diperoleh suatu sumber baik berupa lisan maupun tulisan yang dapat dipercaya dan dapat digunakan oleh peneliti. Selanjutnya, peneliti kemudian menyusun hasil-hasil penelitian (catatan faktafakta) ke dalam suatu pola yang sesuai dengan sistematika yang telah disiapkan sebelumnya dan menyajikannya dalam suatu cara yang dapat menarik perhatian serta mengkomunikasikannya kepada para pembaca sehingga dapat dipahami.

\section{HASIL PENELITIAN DAN PEMBAHASAN}

Bagian ini, penulis akan menguraikan mengenai hasil penelitian dan pembahasan yang telah diperoleh melalui beberapa tahapan yang telah diuraikan dalam pembahasan sebelumnya. Organisasi PASI merupakan organisasi wanita yang bergerak dalam lingkup pemberdayaan kaum perempuan di Jawa Barat. Organisasi ini, selain dikenal sebagai organisasi yang aktif memajukan kehidupan sosial dan pendidikan kaum perempuan, akan tetapi dikenal juga sebagai organisasi yang tetap melestarikan adat dan kebudayaan Jawa khususnya kebudayaan Sunda. Organisasi ini tidak hanya diperuntukan bagi kaum perempuan yang berada di Jawa Barat saja, 
melainkan diperuntukan pula bagi mereka yang mencintai dan ingin melestarikan adat dan kebudayaan Sunda. Sebagaimana hasil penelusuran yang telah dilakukan oleh penulis, pada dasarnya organisasi ini didirikan oleh Paguyuban Pasuban beserta 8 aktivis perempuan lain yang tergerak hati dan kepeduliannya untuk memajukan kehidupan kaum perempuan dan memberikan pembinaan bagi perempuanperempuan yang tidak mendapatkan pendidikan yang layak.

\section{Pergerakan Kaum Perempuan di Indonesia Sebelum Berdirinya Organisasi Pasundan Istri}

Melalui gagasan politik etis pemikiran mengenai peningkatan kesejahteraan pendidikan didukung oleh kaum demokrat liberal yang pada akhirnya membuat pemerintah harus membentuk lembaga pendidikan. Pemerintah lalu membuka sekolah untuk mendidik calon-calon pekerja yang terlatih dan terampil pada bidang pekerjaan yang diperlukan. Pendidikan itu kecuali memberi latihan praktis pada akhirnya tujuan yang ingin dicapai adalah kesejahteraan demi meningkatkan derajat dan persamaan kedudukan dalam masyarakat. Politik etis yang diberlakukan oleh pemerintah Hindia Belanda memberikan kesempatan kepada penduduk bumiputera untuk memperoleh fasilitas pendidikan.

Namun objek yang lebih mendapatkan pendidikan adalah kaum laki-laki, sedangkan kaum perempuan mendapatkan diskriminasi dan keterbatasan untuk memperoleh akses pendidikan. Adanya diskriminasi dan keterbatasan pendidikan tersebut, menjadikan perempuan bangkit untuk memperoleh fasilitas pendidikan. Kaum perempuan Indonesia dirasa sangat perlu untuk belajar dan mendapatkan hak pendidikan, karena dengan pendidikan akan mengangkat martabat kaum perempuan dan dinding feodalisme yang membatasi potensi perempuan dapat dirobohkan.

Dampak dari adanya pendidikan dalam kalangan kaum perempuan terpelajar memberikan pengaruh besar dalam sejarah pergerakan bangsa Indonesia. Hal ini tidak terlepas dari peranan kaum perempuan yang mulai bergerak untuk melawan segala ketertinggalan dan ketidakadilan yang dialami bangsa Indonesia pada saat itu terutama ketidakadilan dan penindasan terhadap hak-hak kaum perempuan. Adanya kesempatan belajar tersebut berdampak pada muncul suatu kesadaran dan kepekaan kaum perempuan yang lebih besar akan masalah yang dihadapi perempuan pada umumnya. Terutama pada permasalahan yang sedang dihadapi bangsa mereka yang masih terdiskriminasi oleh bangsa lain. Maka perkembangan selanjutnya pergerakaan perempuan mulai terwadahi dalam beberapa jenis aliran organisasi.

Kesadaran yang muncul dari fenomena disekitar mereka memberi inspirasi kepada para kaum perempuan terdidik bahwa cara kerja secara individual menghasilkan efek yang kurang memuaskan dan untuk mendapatkan cita-cita bagi kemajuan perempuan dan meninggikan derajat bangsanya mereka menganggap perlunya kerjasama yang luas dan lebih besar dalam bentuk pengikat organisasi agar hasilnya lebih tampak. Caranya dengan membuat semacam suatu pertemuan yang mewadahi seluruh organisasi-organisasi perempuan yang ada di Indonesia untuk menyatukan kekuatan menghadapi belenggu ketetidakadilan dan penyelewengan 
hak-hak bagi kaum perempuan. Maka dilaksanakanlah Kongres Perempuan Indonesia di Yogyakarta sebagai manifestasi dari kesadaran nasional kaum wanita.

Kongres Perempuan Indonesia yang pertama ini bertujuan mempersatukan cita-cita dan memajukan kaum perempuan Indonesia serta membuat gabungan organisasi wanita. Oleh karena itu pelaksanaan kongres ini memang layak diakui sebagai titik awal pergerakan perempuan yang sangat berarti. Dalam Kongres I tersebut menurut Kowani (1978, hlm. 4) para wakil organisasi atau perkumpulan perempuan sempat menanamkan semangat kebangsaan di kalangan kaum perempuan Indonesia serta membahas dan memperjuangkan peningkatan kehidupan kaum perempuan dalam hukum Islam, memperjuangkan hak pilih aktif bagi perempuan dalam perkawinan dengan membentuk suatu komisi untuk merancang peraturan perkawinan modern.

Banyak hal penting yang diperjuangkan untuk kemajuan kaum perempuan pada saat itu. Pokok-pokok permasalahan yang dibicarakan pada kongres pertama ini adalah membahas tentang kedudukan wanita dalam perkawinan, poligami dan koedukasi. Masalah-masalah yang dirembuk dalam pidato-pidato pada saat kongres tersebut, kemudian dituangkan ke dalam edisi khusus majalah Isteri yang merupakan salah satu prakarsa yang lahir pada kongres tersebut. Asas pergerakan kebangsaan Indonesia merupakan ciri utama dari kesatuan pergerakan perempuan Indonesia sebelum tahun 1930.

\section{Pasundan Istri Periode Pemerintahan Hindia-Belanda 1930- 1942}

Pada periode ini karakteristik perjuangan organisasi Pasundan Istri lebih cenderung memperjuangkan hak perempuan dalam bidang peningkatan derajat kaum perempuan dengan tidak menyerang kedudukan kaum pria. Upaya tersebut diantaranya adalah dengan pemberdayaan dalam lingkup Sosial dan Budaya seperti permasalahan perkawinan, hukum islam dan koedukasi. Selain itu PASI turut aktif pula dalam melestarikan budaya Sunda/ Jawa Barat seperti selalu membiasakan menggunakan bahasa Sunda sebagai bahasa ibu dalam setiap pertemuan dan mengadakan pagelaranpagelaran dalam rangka melestarikan warisan budaya leluhur.

Selanjutnya dalam lingkup pendidikan dengan melakukan segala usaha yang dapat menunjang dalam memajukan harkat dan martabat serta pemberdayaan perempuan demi terciptanya kualitas sumber daya manusia yang mumpuni. Upaya tersebut dituangkan kedalam sebuah kegiatan belajar mengajar seperti membaca dan menulis serta penddidikan eetika dan sopan santun. Agenda kegiatan yang rutin dilaksanakan berfokus kepada usaha-usaha pemberdayaan yang diperuntukkan bagi kaum perempuan. Usaha yang dilakukan seputar pemberian pendidikan dan keterampilan yang dapat mengasah potensi perempuan dengan mendirikan sekolah-sekolah kejuruan yang menggunakan bahasa Belanda dan bahasa Sunda. Usaha-usaha yang dinilai dapat meningkatkan kualitas hidup kaum perempuan yang berada di Jawa Barat, yakni sebagai berikut: 
FUJI ASTUTI DAN YANI KUSMARNI

REKAM JEJAK PERJUANGAN PASUNDAN ISTRI (PASI) DI BANDUNG 1930-197O

1. Kursus untuk wanita mengenai pengetahuan umum, kerumahtanggaan, kesehatan dan pendidikan.

2. Valkschool untuk gadis, Atikan Murangkalih Istri (AMI) yang berada di Bandung, Tasik, Bogor dan Cianjur.

3. Tempat pendidikan dan penampungan kaum buruh wanita dari golongan rakyat jelata yang tidak mempunyai pekerjaan. Tempat tersebut dinamakan Penolong Pengangguran Kaum Ibu yang didirikan di Jatinegara dan Tasikmalaya serta di tempat yang dirasa memerlukan penampungan ini.

4. Rumah nenek jompo dan yatim piatu.

Ada beberapa macam kursus yang diselenggarkan oleh organisasi PASI untuk para anggota, yaitu kursus kerajinan tangan, memasak, bahasa belanda dan teori menjahit atau menyulam. Kegiatankegiatan yang bertujuan diperuntukkan bagi anggota PASI maupun masyarakat umum ini dimaksudkan untuk dapat mempererat persaudaraan dan mengangkat harkat derajat kaum wanita dengan jalan mengutamakan Pendidikan dan Sosial, melalui pembentukan beberapa cabang PASI di Jawa Barat, diharapkan dapat dengan mudahnya meningkatkan kualitas kaum perempuan di tatar Sunda

Diharapkan dengan adanya usaha tersebut, sedikit demi sedikit dapat membawa perubahan yang bersifat kemajuan dalam kehidupan kaum perempuan dan anak-anak sebagai generasi penerus bangsa. Organisasi PBI didirikan bukan hanya diperuntukan bagi kaum perempuan Sunda saja, akan tetapi diperuntukan pula bagi semua perempuan bumiputra yang berkepentingan di Pasundan dan setuju dengan maksud
PASI. Menurut Amin (2013, hlm. 134) pula dijelaskan bahwa disebutkan dalam reglament Pasal 3 yang berbunyi "sekalian istri Indonesia yang setuju dengan maksud Pasundan Istri bisa menjadi anggota asal umurnya tidak kurang dari 18 tahun dan sudah keluar dari sekolah”. Bahkan mereka yang bukan istri Indonesia pun dapat diterima menjadai donator, hanya tidak mempunyai hak suara dan tidak boleh menghadiri rapat.

KemudiandalamlingkupekonomiPASI berusaha mengupayakan peningkatan, pengembangan usaha untuk membantu ekonomi lemah melalui pembentukan koperasi berbadan hukum, dan Program Kredit Dakabalarea (khusus di Jawa Barat). Selanjutnya PASI mengupayakan pula peningkatan kualitas pengurus dan anggota di bidang perkoperasian dengan mengikut sertakan pengurus dalam pelatihan khusus dalam bidang perniagaan. PASI dibawah kepemimpinan Emma ini berhasil membawa kaumnya merintis ke jalan kesederhanaan menyusun latar hidup dengan mencari keseimbangan antara kemampuan dan pendapatan suami.

Menururt DPP Pasundan Istri (2005, hlm. 26) dengan usaha tersebut, PASI membimbing anggota-anggotanya untuk belajar menabung, usaha ini tidak lain daripada persiapan koperasi, yang kemudian dalam tahun 1931 dibentuklah "Simpanan PASI Bandung" atau S.P.B dan sekarang lebih dikenal dengan "Koperasi Bank Wanita”. Hal ini mendapat respon yang baik dari anggota PASI maupun masyarakat Bandung, karena respon yang baik tersebut munculah kemudian Koperasi Wanita di kabupaten yang terdapat cabang PASI, dan sudah memiliki hak badan hukumnya. Dari usaha menabung kemudian berkembang menjadi usaha 
simpan pinjam. Hal ini dimaksudkan untuk memberikan kesempatan kepada anggota untuk dapat mengatasi masalah ekonomi rumah tangganya. Melalui bantuan tersebut, kaum perempuan di Jawa Barat dapat meningkatkan taraf kehidupannya. Hasil daripada tabungan tersebut salah satunya digunakan untuk mempraktekan hasil-hasil kursus yang diselenggarakan PASI.

Kemudian titik perjuangan PASI pada masa selanjutnya berusaha menumbuhkan kesadaran nasional untuk mencapai cita-cita kemerdekaan dengan melalui persatuan dan kesatuan bangsa. Dalam kesempatan itu pula, organisasi PASI berupaya untuk memperjuangkan hak pilih aktif bagi perempuan sebagai bagian dari bangsa Indonesia, akan tetapi perjuangan hak pilih tersebut tidak terlalu menjadi fokus utama bagi PASI. Selanjutnya setelah masa pemerintahan Hindia-Belanda berakhir, dengan dibuktikan oleh pemerintah kolonial menyerah kepada pemerintah Jepang. Masa pendudukan Jepang selama tiga setengah tahun turut menjadi sejarah bagi bangsa Indonesia. Adapun karakteristik perjuangan organisasi PASI pada masa ini adalah sebagai berikut

\section{Pasundan Istri Periode Pemerintahan Jepang 1942-1945}

Sampai pada masa pendudukan Jepang di Indonesia, tahun 1942 menjadi titik awal kemuduran pergerakan organisasi. Bahwa bangsa Indonesia tidak dapat secara bebas bergerak, karena setiap gerak-gerik yang dilakukan selalu berada dibawah pengawasan pemerintah Jepang. Pada masa pendudukan Jepang di Indonesia tahun 1942, pemerintah Jepang memanfaatkan perempuan- perempuan pribumi dengan membentuk organisasi perempuan bernama Fujinkai. Menurut Suryocondro (1984, hlm. 133135), organisasi bentukan Jepang ini beranggotakan istri pegawai negeri dan memiliki kemiripan dengan Dharma Wanita (organisasi-organisasi istri para pejabat sipil).

Perempuan-perempuan pribumi di Indonesia diwajibkan untuk mengikuti organisasi Fujinkai yang merupakan organisasi pertahanan khusus perempuan pada masa pendudukan Jepang. Fokus kegiatan Fujinkai ini ialah melakukan pemberantasan buta huruf dan berbagai pekerjaan sosial. Dalam tubuh Fujinkai, kaum perempuan pribumi bekerja mempersiapkan diri untuk kepentingan pemerintah Jepang seperti memintal, bercocok tanam dan berkoperasi.

Berdirinya Fujinkai mendapatkan pertentangan dari aktifis kaum perempuan Indonesia. Serta dengan adanya Fujinkai, maka organisasi PASI sebagai organisasi kaum perempuan yang telah mengakar di Jawa Barat, oleh pamerintahan Jepang dilarang melakukan gerakan sosial, yang berwenang hanyalah Fujinkai. Sejalan dengan ketentuan tersebut, maka kegiatan sosial dan pemberdayaan kaum perempuan di Jawa Barat terpaksa diberhentikan. Hal ini dialami pula oleh organisasi PASI sebagai organisasi pergerakan kaum perempuan di Jawa Barat. Meskipun ruang gerak organisasi dibekukan, akan tetapi PASI masih berjuang demi kepentingan kaum dan bangsanya dengan melakukan system pergerakan "bawah tanah". Dalam pelaksanaannya Emma Poeradiredja selaku ketua dan pendiri beserta anggota-anggota organisasi PASI lainnya secara diam-diam terus melakukan kegiatannya. Pergerakan ini dilakukan oleh anggota PASI secara 
sembunyi-sembunyi untuk menghindari penyergapan dan pembunuhan yang dilakukan oleh pemerintah Jepang. Meskipun secara formal PASI dilebur kedalam organisasi Fujinkai, secara persaudaraan tetap berkelompok dan melakukan kegiatan-kegiatan sosial dan pembinaan seperti biasa.

Setelah Jepang mengalami kekalahan dari Sekutu pada Perang Dunia ke II serta adanya Proklamasi Kemerdekaan Indonesia pada tahun 1945, maka peran dari organisasi perempuan mengalami peningkatan kembali. Dengan membubarkan Fujinkai, organisasi PASI kemudian membentuk barisanbarisan untuk mendukung perjuangan dalam mempertahankan kemerdekaan. Pengalaman-pengalaman selama bergabung dengan Fujinkai dimanfaatkan untuk kepentingan perjuangan. Hal ini dibuktikan dengan turut sertanya kaum perempuan berjuang bersama kaum lakilaki dan bahu-membahu mengangkat senjata untuk bertempur dalam medan perang melawan pemerintah Belanda yang ingin berusaha merebut kembali Indonesia merdeka.

\section{Pasundan Istri Periode Setelah Kemerdekaan 1945-1970}

Begitu pula pada periode setelah kemerdekaan pergerakan organisasi PASI berbenah diri untuk menggalang persatuan yang kuat. Menurut Wieringa (1999, hlm. 316) melalui kongres pertama setelah kemerdekaan yang diadakan di Klaten pada bulan Desember 1945, dengan maksud menggalang persatuan dan membentuk badan persatuan. Persatuan Wanita Indonesia (PERWANI) dan Wanita Negara Indonesia (WANI) dilebur menjadi badan fusi dengan nama Persatuan Wanita
Republik Indonesia (PERWARI). Hasil kongres tersebut berdampak kepada upaya yang dilakukan PASI untuk berpartisipasi dalam rangka kemajuan bangsa Indonesia.

Upaya pergerakan yang dilakukan oleh organisasi PASI berkembang ke arah perpolitikan. Permasalahan perempuan yang dipandang domestik (perkawinan dan perceraian) yang sempat muncul pada masa sebelumnya kembali ditransformasikan oleh oranisasi PASI beserta organisasi kaum perempuan lain di Indonesia menjadi agenda publik negara. Menururt DPP Pasundan Istri (2005, hlm. 5) organisasi PASI berusaha merubah Anggaran Dasar dengan dasar Pancasila dan UUD 1945. Pada periode ini perjuangan "hak perempuan" berlangsung di lingkup "negara" yang bertujuan untuk meneguhkan identitas kewarganegaraannya secara otonom. Dukungan partai politik turut serta mendekatkan isu perempuan ini melalui pembuatan kebijakan Negara. Hal tersebut sejalan dengan penjelasan menurut Kowani (1978, hlm. 16-24) pada periode selanjutnya kegiatan PASI diarahkan berperan serta dalam pembangunan nasional, meningkatkan kualitas manusia Indonesia berdasarkan Pancasila, Undang Undang Dasar 1945 dan amanat cita-cita proklamasi kemerdekaan RI 17 Agustus 1945.

Pada bulan 26 Agustus 1949 organisasi PASI turut dalam musyawarah Wanita Indonesia di Yogyakarta. Menurut Janti (2018) pihak yang memprakarsai Permusyawaratan Wanita Seluruh Indonesia adalah Kowani yang dihadiri oleh 82 orang orang yang tergabung di dalam organisasi wanita seluruh Republik Indonesia. Panitia Permusyawaratan Wanita Seluruh Indonesia ini diketuai 
oleh Ny. Burdah Yusupadi dan anggotanya terdiri dari. Ny. Siti Sukaptinah, Sunaryo Mangunpuspito, Ny. Mr. Maria Ulfah Santoso, Ny. Supeni, Ny. S Akhmad Natakusumah, dan Ny. Th. Waladouw. Banyak peserta yang berasal dari luar Jawa harus melalui perjuangan karena harus terlebih dahulu melewati daerah yang masih diduduki oleh Belanda.

Sekitartahun1960-anpergerakankaum perempuan di Indonesia dapat dikatakan sebagai periode penghancuran gerakan perempuan Indonesia, yang titik awalnya dilakukan melalui penghancuran terhadap Gerwani (Gerakan Wanita Indonesia) melalui kampanye media massa antara 10 Oktober 1965-12 Oktober 1965. Gerwani sebagai organisasi massa perempuan telah diberangus oleh rezim Orde Baru dan aktivisnya kemudian ditangkap, dibuang ataupun dibunuh sejak itu hingga 1968. Sejak militer Orde Baru berkuasa melalui penghancuran citra gerakan perempuan kerakyatan yang melawan adat dan imperialisme, maka tidak dibenarkan kaum perempuan memperjuangkan hak perempuan dan ideologi-politiknya. Menurut Cokrowinoto (1988, hlm. 189) gerakan yang diperbolehkan adalah menjalankan program nasional, yakni Keluarga Berencana dan menjadi anggota organisasi isteri yang disebut Dharma Wanita (untuk isteri PNS) dan Dharma Pertiwi (untuk isteri ABRI). Sedangkan untuk perempuan kampung yang bukan isteri PNS maupun ABRI diarahkan untuk aktif di PKK, Posyandu atau pun menjadi penyuluh KB. Agar kaum perempuan tidak melanggar aturan ini, maka dikemaslah sebuah ideologi peran yang disebut Panca Dharma Wanita, dan kaum perempuan dikontrol oleh suami atau penjabat negara dari lokal hingga pusat.
Periode ini membuat gerakan organisasi PASI dan organisasi kaum perempuan lainnya hanya menjadi alat mobilisasi politik rezim militer. Adat dan paham tua dikembangkan kembali untuk proses penaklukan daya kritis organisasi perempuan. pada tahun 1967 organisasi PASI aktif kedalam Sekber (Sekretariat Besar) Golkar, lalu setelah berubah menjadi Golongan Karya organisasi PASI tidak aktif kembali. menurut DPP Pasundan Istri, PASI akan fokus ke dalam usaha pemberdayaan kaum perempuan tetapi PASI memperbolehkan anggotanya untuk ikut aktif dalam perpolitikan.

Organisasi PASI merupakan salah satu organisasi perempuan yang aktif di dalam perjuangan Indonesia. Dasar perjuangan organisasi Pasundan Istri bertujuan untuk kemajuan kaum perempuan. Secara umum kiprah perjuangan yang dilakukan oleh organisasi PASI di Bandung pada tahun 1930-1970 memiliki karakteristik tersendiri yang membedakan dengan organisasi perempuan lain. Karakteristik pergerakan organisasi PASI dipengaruhi oleh faktor-faktor salah satunya faktor situasi dan kondisi pemerintahan pada saat itu mendominasi. Hal tersebut menjadikan pergerakan organisasi PASI menjadi suatu organisasi pemberdayaan perempuan di Jawa Barat yang dapat menyesuaikan dengan tuntutan jaman seraya tidak lepas dari kodratnya sebagai perempuan Sunda.

\section{Dampak dari perjuangan Organisasi Pasundan Istri (PASI) terhadap pendidikan kaum perempuan tahun 1930-1970}

Pendidikan formal yang dibentuk oleh PASI memiliki kecenderungan untuk memberikan pendidikan kepada anakanak dan perempuan. PASI menganggap 
hal tersebut bahwa dengan memberikan pendidikan pada anak-anak khususnya anak-anak perempuan dapat dengan mudah membentuk karakter manusia yang diharapkan sejak dini.

Berikut merupakan daftar Sekolah Binaan Cabang Pasundan Istri, yaitu: TK Wirangrong (Bandung), TK Sapu Jagat (Bandung), TK Taman sari (Bandung), Tk. Ence azis (Bandung), TK Nusa Indah (Kuningan), TK Batu Tulis (Bogor Selatan, dan TK Palmerah (Jakarta), TK Pasi (Cianjur).

Melalui pembentukan Taman Kanakkanak (TK), berusaha memberikan berbagai contoh dan kegiatan positif yang akan diingat dan praktikkan dalam kehidupan nanti. Pendidikan TK bertujuan mengenalkan anak-anak pada bidangbidang pelajaran ataupun melatihnya berinteraksi dengan teman sebaya.

Organisasi PASI selalu berusaha memberikan pendidikan etika dan sopan santun serta keterampilan-keterampilan lainnya diadakan di seluruh tingkat kepengurusan melalui pengisian acara pada pertemuan anggota. Selain itu pula PASI berusaha memberikan keterampilanketerampilan kepada masyarakat pada umumnya dengan mendirikan suatu lembaga masyarakat yang dapat membantu meningkatkan kualitas SDM di Jawa Barat. Beberapa lembaga tersebut diantaranya mendirikan Lembaga Penolong Pengangguran Kaum Ibu (PPKI) dan mendirikan Yayasan Beribu di Bandung.

Melalui pembentukan lembaga pendidikan formal dan non-formal di beberapa cabang ini, organisasi Pasundan Istri berusaha membentuk pola pikir kaum perempuan mengarah ke kemajuan. Diharapkan dengan adanya pendidikan yang diberikan kepada kaum perempuan terutama pendidikan bagianak-anak, dapat membawa pengaruh yang cukup besar terhadap kemajuan bangsa Indonesia.

\section{SIMPULAN}

Karakteristik organisasi Pasundan Istri dengan organisasi perempuan lain yaitu PASI lebih bersifat egaliter. Dalam hal ini berarti organisasi PASI secara tegas berupaya untuk memberikan pendidikan yang luas bagi perempuan, menumbuhkan rasa empati yang tinggi dan upaya pelestarian seni dan budaya daerah khususnya budaya Sunda. Langkah garapan tersebut salah satunya dituangkan kedalam bidang pendidikan. Dari segi aspek pendidikan, pendidikan yang diberikan adalah pendidikan yang tidak melupakan akar budayanya selaku bangsa Jawa terutama suku Sunda. Meskipun pada saat itu banyak anggota PASI yang fasih berbahasa Belanda, akan tetapi bahasa Sunda masih tetap dilestarikan dan dianggap sebagai "bahasa ibu" dalam setiap kegiatannya. Kegiatan-kegiatan yang bersifat menjunjung budaya Sunda selalu rutin dilaksanakan, merupakan suatu ciri khas dari organisasi PASI. Selain itu PASI fokus dalam usaha pemberdayaan dan pemberian pendidikan yang luas seperti pemberian kursus-kursus bahasa Belanda, menulis, mambaca serta kursus keahlian sepertian memasak dan menjahit. PASI beranggapan bahwa pendidikan bagi perempuan adalah jalan untuk pembebasan kaum perempuan terhadap keterbelakangan wawasan dan ilmu pengetahuan.

Usaha pemberdayaan yang dilakukan oleh organisasi Pasundan Istri mendapatkan respon yang sangat baik dari masyarakat, Hal ini dibuktikan 
dengan berdirinya cabang-cabang PASI di Jawa Barat. Dalam setiap cabang tersebut didirikan koperasi dan sekolahsekolah serta yayasaan yang didirikan dan dikelola oleh organisasi PASI. Sekolah-sekolah formal yang didirikan oleh PASI lebih cenderung undergrowth atau sekolah-sekolah yang diperuntukkan bagi anak-anak. PASI menganggap hal tersebut bahwa dengan memberikan pendidikan pada anak-anak khususnya anak-anak perempuan dapat dengan mudah membentuk karakter manusia yang diharapkan sejak dini, mengingat pengalaman yang didapat dalam periode ini turut membentuk kepribadiannya dan akan memengaruhi sosoknya hingga dewasa. Maka dari itu PASI dengan melalui pembentukan Taman Kanak-kanak (TK), berusaha memberikan berbagai contoh dan kegiatan positif yang akan diingat dan praktikkan dalam kehidupan nanti. Pendidikan TK bertujuan mengenalkan anak-anak pada bidang-bidang pelajaran ataupun melatihnya berinteraksi dengan teman sebaya. Kemudian melalui pembentukan lembaga pendidikan sosial seperti Yayasan Beribu dapat membawa kaum perempuan pada peningkatan kualitas kehidupan bagi kaum perempuan di Jawa Barat. Secara berangsur-angsur timbul dorongan dalam diri perempuan untuk mulai berfikiran luas, salah satunya timbul suatu kepercayaan bahwa suatu bangsa hanya dapat maju apabila kaum perempuan dan kaum laki-laki bekerja sama bahu-membahu untuk tujuan yang lebih tinggi yakni kemerdekaan bangsa Indonesia.

\section{DAFTAR PUSTAKA}

Amin, S. (2013). Paguyuban Pasundan 1914-1942. Bandung: Pustaka Jaya.
Cokrowinoto, (1988). Analisa Situasi Wanita Indonesia. Jakarta: Kantor Menteri Negara UPW.

DPP Pasundan Istri. (2005). 75 Tahun Melintasi 3 Zaman Pasundan Istri. Bandung: DPP Pasundan Istri.

Fatimah, S. (2008). Perspektif dalam Historiografi Indonesia: Pentingnya Penulisan Sejarah Androginous. Jakarta: Wedatama Widya Sastra dan Departemen Sejarah FIB UI.

Gottschalk, L. (1986). Mengerti Sejarah. Jakarta: UI Press.

Ismaun. (2005). Pengantar Sejarah Sebagai Ilmu dan Wahana Pendidikan. Bandung: Historia Utama Press.

Kowani. (1978). Sejarah Setengah Abad Pergerakan Wanita Indonesia. Jakarta: Balai Pustaka.

Sjamsuddin, H. (2012). Metodologi Sejarah. Yogyakarta: Ombak.

Supardan, D. (2007). Pengantar Ilmu Sosial Sebuah Kajian Pendekatan Struktural. Jakarta: Bumi Aksara

Suryocondro, S. (1984). Potret Pergerakan Wanita di Indonesia. Jakarta: C.V. Rajawali.

Janti, N. (2018, 28 Juli). "Perempuan Pertama di Parlemen Bandung". [Forum Online]. Diakses d a r i https://historia.id/persona/articles/ perempuan- $\quad$ pert a m a - d i parlemen-bandung-PM1EX

Indraswari, G.I. \& Yulifar, L. (2018). Surastri Karma Trimurti: Menggugat Hak-hak Kaum Buruh Perempuan Indonesia Tahun 1945-1954. Factum: Jurnal Sejarah dan Pendidikan Sejarah, VII, 67-78. doi: h t t p : / / ejournal.upi.edu/index.php/factum/ article/view/11928/7183 